\title{
Ondo in the History of Aso-Òkè Weaving in Southwestern Nigeria
}

\author{
Ademuleya, Babasehinde Augustine. Ph. D \\ Department of Fine and Applied Arts, Obafemi Awolowo University, Ile-Ife, Nigeria \\ sehindeademuleya@oauife.edu.ng
}

\section{Doi:10.5901/mjss.2014.v5n20p2127}

\section{Abstract}

The Òndó people are known for their consistent use of the old aso-òkè types, over the yea. which perhaps must have influenced the thought in some quarters that the Òndó people have a long history of the narrow strip weaving tradition. This study however reveals that the Ondó indigenes are not weavers of aso-okè, the narrow strip cloth, but good merchants and patrons of the old aso-òkè types. It also attributes the sustenance of the weaving industry that thrived in the town in the early part of the 20th century to the migrant weavers from Iseyin and llorin.

Keywords: Aso-Òkè, Ondo, Narrow Strip Weaving, Yoruba.

\section{Introduction}

Ondo town is located in the South-eastern part of Yorùbá Kingdom, about 64 kilometers from its location to lle-lfe and about 45 kilometers south of Akure, the Ondo State capital. The people of the town claim to have descended from Odùduwà, the progenitor and founder of the Yorùbá race. The kingdom situated in the tropical rainforest, hence the people have always engaged in farming, an occupation that is mostly practiced by men. Farming is the mainstay of Ondo's economy.

Before the introduction of cocoa and rubber to Ondo in the early twentieth century, the people are known for production of kolanut, pàkálà (local beans), plantain, yam and some other foodstuffs common to the rainforest regions. Apart from farming and trading, there are many other special occupations, which are exclusive to certain lineages. Prominent among these are blacksmithing, and brass-smiting, popularly known as Lágbède, drumming and dancing, and hunting. There also exist some other crafts practiced by individuals within the family or the clan which are mainly to service the domestic needs of their immediate or extended families. Among such crafts is broad loom weaving tradition practiced by women.

Another noticeable occupation of the Ondo people, which predates colonial rule, is trading. Some of the people are petty traders; aláròóbò, who hawk their wares within the town, and some are merchants who attend and exchange goods at major markets in other towns and villages. In addition to food commodities and other common household items, an important article of trade of the Ondo merchants is the locally woven cloth commonly called aso-òkè. It is an occupation dominated by women. This study, attempts to ascertain the level of involvement of the Ondo people in the manufacture of aso-òkè, the narrow loom cloth.

The Yorùbá name for loom is òfi, hence, the cloths made on loom are called aso-òfi or aso-òkè "meaning cloths from the hinterland." There are two types of looms; the vertical (broad) loom used mostly by women and the horizontal (narrow) loom, traditionally used by men. Although the term refers generally to products of the two (broad and narrow) looms, it is however, more closely associated with the weaves from the horizontal loom and cloths made with it. The three major Yorùbá traditional hand woven aso-òkè are: etù, àlàarì, and sányán, the last is pronounced sánmíyán in Ondo. Sanyan is usually of plain pale grayish brown color, sometimes with white longitudinal warp lines. It is traditionally made of yarn derived from spun nest of anaphe caterpillar. Àlàári is crimson in color, originally made from a mixture of sanyan dyed in red camwood and imported alharini thread (Aronson 1992). Not all àlàarì are of pure red color, some are combined with dyed cotton of various colors and patterns. Etù is predominantly dark blue (indigo) with fine light blue at its background. It is usually made of indigo dyed cotton. The earliest ones are said to have contained a considerable proportion of sanyan silk (Lamb and Holmes, 1980). Very close to etù is petùje which is often called junior etù. It has small checks of light blue on a dark indigo background. 


\section{Aso-Òkè in Ondo History}

Like in many other Yorùbá towns, it is generally believed that, cloth weaving must have been one of the craft practices in and around Ondo area for a long time but how extensively it had been practiced remains very scanty, even in Ondo local tradition. History has it that before the British intervention and "opening up" of the town in the 1870s, the Ondo people had been using aso-òkè and have had course to relate or trade with some known aso-òkè weaving centers in Yorubaland. The Ondo chroniclers: Rev. Leigh (1917), Johnson (1921), Chief Ojo, Bada of Shaki (1962), Ogunsakin (1976) and Adeyemi (1993) as well as Awogbamye (personal communication, December 15, 1999) in their efforts at reconstructing Ondo history recorded varied and conflicting accounts of Ondo's contact with the Oyo, lle-Ife, ljebu and Edo people. Of all these, the contact with the Oyo seems most relevant to this paper.

Ogunsakin (1976), Johnson (1921) and Awogbamiye (personal communication, December 15, 1999), corroborate each other on the contact with Oyo, though, with slight differences in details on the time and the order in which certain Oba reigned. According to Ogunsakin (1976), Púpùpú the first Òsemàwé of Ondo, whom he claimed to be an Oyo princess, was said to have sent goodwill messages to Aláàfin Eguguoju who reigned at Oyo-lgboho on her ascension of the throne as Osemawe. Ogunsakin also informed that Oba Luju, the third Osemawe visited Oyo during the reign of Alaafin Ajiboye who celebrated Bèbè festival, a triennial event at Igboho, and presented him with gifts. Luju was said to have brought back with him the style of administration and architectural form of the Alaafin's palace as a model for rebuilding his own palace. Since the lavish use of prestigious cloths was one of the hallmarks of the Bebe festival (Johnson 1921), it is likely that Oba Luju might have used the opportunity of his visit to import varieties of aso-òkè for the royal house at Ondo.

Adeyemi (1993) and Awogbamiye (personal communication, 1999) also informed of the friendship between Osemawe Leyo and Alaafin Ayibi of Oyo. According to both, the friendship was so deep to the extent that both supported each other with troops during war campaigns. According to Awogbamiye, it was this action that won for the Oba Leyo the cognomen Olóógun L'êyó, meaning "He who has troop in Oyo" when the Alaafin sent troops to reinforce Leyo's troops when Ondo was being attacked. The nickname was later contracted to Leyo. Olupona (1992) also reported that Osemawe Jogunde who reigned in Ondo around 1759 was a close friend of Alaafin Majeogbe. The significance of highlighting these contacts is not to support or reject some scholars' assent to the Oyo origin of Ondo but to point out the possibilities of Oyo influence on Ondo dress culture, particularly in the use of aso-òkè.

Besides the link discussed above, there are some other claims of Ondo's extensive involvement in cloth weaving before the 20th century, Ene (1964) claimed that the indigenous silk spun from anaphe cocoons was used in time past in Ondo town ever before the coming of the Europeans. Some indigenes often refer to the large presence of trees that produce cotton and those that accommodate the anaphe - caterpillar which produce the yarns for weaving in Ondo as a possible factor (Patrick Akinbuli, personal communication, 1999).

Another important factor is the existence in Ondo vocabulary, the names of these trees. Öwú èkèsé is the name for cotton spun into major yarn (in traditional times) for the manufacture of ẹtù and àlàárì. Ewùkù, on the other hand, is the name for silk spun into yarn for sanyan. Ewùkù is also the Ondo name for the caterpillar that produces the cocoon, which the Ondo relish as a delicacy and was available in their markets in the past. This linguistic evidence and other related claims must have informed Akinlami's claim of the art of cloth weaving was an age-long industry in the town (personal communication, 1999). Ogunsakin (1976) also believed that hand-loom weaving must have been the specialty of the Ondo through the centuries. He added that the skilful fingers of women wove the varieties of the hand loomed aso-òkè for which the Ondo have earned a countrywide fame. Mama Adeduro who also informed that her aunt was a weaver in her lifetime confirmed Ogunsakin's claim that women were weavers in Ondo (personal communication 1999) ${ }^{1}$. While these claims of Ondo's involvement in the weaving of aso-òkè cannot be totally ignored, it is to be noted that there exists no evidence of Ondo indigenes as aso-òkè weavers, to support the claims, even in Ondo oral tradition.

There are also certain aspects of the claims that are contradictory. For instance, craft practices among the Yorùbá people are organized according to guild system, they are generally a lineage or family affair from which names and praise names are derived. While there exists, even to date, names of individuals and or oríki -idilé - family praise chants which reflect the lineage craft tradition such as blacksmithing - Lágbàde, brasssmithing - Lágogo-Ide etc., among the Ondo, no praise name reflects weaving tradition. Corroborating this, Mama Oshowo, from Ondo and Yeye Chief Adepoju, the Sàréré-Lóbùn of Ile-Oluji, both prominent aso-oke merchants, noted that no Ondo man or woman can boast of his or her great grandfather who was a great weaver (personal communication, 1999). Although Ogunsakin (1976) in his claim of women in Ondo as weavers did not specify period of their involvement, but from Mama Agnes Adeduro's account, the period seems more recent than ancient, supposedly around the beginning of the 20th century (personal communication, 1999.). It is not impossible that the wooden hand-loom so referred to by Ogunsakin (1976) could have been the upright 
broad loom popularly used by women. Akinlami's assertion that Ondo women of old used the traditional broad loom supports this (personal communication, 1999). Yeye Chief Adepoju also corroborates this with her submission that Kitíke, which is woven on the broad loom, was in use in Ondo area ki oju to la meaning "before modernity". It is good to note that the women in Idanre, a neighboring town to the north east of Ondo, were known for their expertise in the use of the broad loom in producing Kitike otherwise known as popoku or kijipà. This same loom is used in producing female ceremonial wraparound, which the Ondo called Lúbò-méji "two wide strip cloth". A common saying: İdànrè e je ètùtù p'Ondo meaning "The Idanre saves the Ondo from dying of cold" further establishes this. This saying, according to Pa Lucas Akinnola of Oke Igbo, was common on people's lips in 'those days' and revealed the fact that the Ondo relied on the Idanre for the supply of Kitíke in the time past (Personal Communication, 2001)2. It further established the fact that the Ondo were not indeed deeply involved in cloth weaving in ancient times, broad- loom weaving inclusive.

It is however not impossible that the Ondo might have been involved in the preparation of some of the materials used for cloth weaving, especially silk and cotton. Mama Mofeade's claim that her mother used to spin cotton, using àkéte (wheel) after which she will sell it to the non indigene weavers, confirms this (personal communication, 1999). This claim also confirms the presence of non- indigene weavers in Ondo.

\section{The Emergence of Horizontal Loom Weavers in Ondo}

The coming of non-indigenes and particularly aso-òkè weavers into Ondo occurred in waves between the 1870s and 1930s. It started with the 'opening up' project of the then colonial government, the end of Ondo Civil war, and the coming of the Christian missionaries as well as the introduction of Islam to Ondo.

The civil war that broke out in the Ondo kingdom around the 1850s led to the abandonment of the capital for about twenty-two years (Awogbamiye, personal communication, 1999). Upon the request of some Ondo traders in Lagos, and some who had fled to Lagos during the crisis, the Chief British representative in Lagos, Captain Goldsworth was sent to Ondo in 1872 to end the civil crisis and to restore peace and order to the city. Coincidentally, the colonial government's intervention came at a time when an attempt was being made by the same government to open an alternative trade route by water through the ljaw country and Ondo to Ibadan. This became necessary due to the incessant wars in the Yorubaland at that period, which had led to the blockade of the road connecting Lagos with Ibadan via ljebu by the Egba and the ljebu warriors. The blockade had made trading with the hinterland impossible (Fajana \& Biggs, 1964).

On his return to Lagos after the successful completion of his assignment, Goldsworth encouraged the Church Missionary Society (CMS) to take up the evangelization of the Ondo area. A survey visit was made to Ondo in 1873 by; Revs. J. A. Maser and E. Roper and a new mission post was opened in 1875 by Rev. David Hinderer. This marked the beginning of an evangelical effort tagged the "Ondo mission". Rev. Hinderer left Ondo in December 1876 and was replaced by Rev. Charles Phillips, a Yoruba-speaking clergyman who later became the Bishop.

The opening-up of the kingdom to serious trading activities and the missionaries' efforts brought tremendous economic prosperity to the Ondo people. Between 1880 and the close of the nineteenth century, the missionary activities of Rev. Phillips had reached Akure, Ekiti, Ikole, Aramoko, Akoko, Owo, Ikale - Ilaje areas and to llesa and lfe to the west. This exercise afforded the Ondo local traders the opportunity to expand their trading activities to most of these areas, which have become easily accessible. The easy link to Lagos by canoe through Agbabu - Lagos water route also elevated some local traders into big time merchants. This breakthrough perhaps led to the coming of the first batch of the large number of non-indigene, fondly called kóolólo ${ }^{3}$ to Ondo. A sizable number of these no-indigenes included itinerant cloth merchants.

Although, there is no evidence to show that weaving of aso-òkè started during this time, it is however certain that the buying and selling of aso-òkè by the female clothiers who moved from town to town exchanging goods from one periodic market to the other must have become prominent. According to Mama Akingbola, her mother who was a prominent clothier in the 1930s, told her, how her own mother used to go to Ibadan on foot to buy aso-òkè. She also said that the aso-òkè sold during her grandmother's era was made entirely of hand spun yarn (Personal Communication, 1999.) $)^{4}$.

The most significant contribution of Rev. Phillips to the economic development of Ondo, which indeed brought a larger number of non-indigenes, including weavers to the town was the introduction of cocoa seed in 1906 (Olupona 1992). Rev. Phillips was not only credited for the introduction of the cocoa seed, he was said to have encouraged his followers to become cocoa farmers. They in turn became wealthy and increased in status. Apart from the growth of cocoa, the development of rubber plantation and timber concessions, which came shortly after, also added to the rapid economic growth experienced in the district in the early twentieth century. This development, as rightly observed by Olupona, led to the creation of new villages and new farm settlements, consequent upon which laborers were hired from 
distant Yoruba towns. This also led to the influx of skilled men who came to provide services, some of which were earlier provided by indigenes who suddenly embraced trading.

Another significant event, which may have been responsible for the presence of a large number of aso-òkè weavers in Ondo kingdom, was the introduction of Islam. About a decade after the establishment of the "Ondo mission", Muslim migrants also entered the town. The earliest migrants include one Abubakr Ajao (or Habeeb), a migrant trader and weaver from Iseyin (Olupona 1992) and Alfa Muhammed Alimi, the recognized first Pilgrim father and the first Chief Imam, who may have come from llorin (Fawehinmi 1991). The two are recognized as the fathers of Islam in Ondo Kingdom. It is also most likely that some Muslims may have come to the town from Lagos, possibly under the auspices of the Ondo traders in Lagos. For instance, Olupona (1992) informed of an entry in Rev. Phillips diary indicates one of his frequent contacts and debates with Lagos Muslims resident in Ondo in November 16, 1880. He observed that Islam became well established in the town between 1883 and 1885. This observation coupled with Islamic oral tradition suggests that active proselytizing spearheaded by Alfa Alimi occurred around 1887. Alfa Alimi used his message of tolerance and generosity to win prominent Ondo elites and high chiefs into Islam. He also integrated himself into the society by emulating the people's dress style. He also describes Alimi as being fond of wearing traditional Yorùbá garb "which the Ondo people were readily identified with".

It is contended here that the introduction of narrow hand-loom weaving and the extensive manufacture of aso-òkè in the Ondo kingdom actually started around the period of 'opening up' of the kingdom and the consequent presence of migrants. It is pertinent to add, that the migrant weavers from Iseyin and llorin, who were the first generation of Muslims in Ondo, must have introduced the aso-òkè weaving industry to the kingdom. In his description of the usual movements of any migrant Iseyin weaver, Alhaji Kazeem Ajadi who himself had worked in ljebu and Abeokuta but is now back at home, said that "... wherever the migrants go to, they go there first as weavers, but if they are able to get another pleasing job they may dump weaving or combine both" (personal communication, 2001).

With the opening-up of the kingdom, which made Ondo easily accessible to the migrant Muslim weavers, their primary focus was business. Their dissemination of Islamic ideas and doctrine was based on the nature of Islam, which makes every Muslim an instrument of conversion, a propagandist of the faith and a missionary of Islam in addition to his daily vocation (Olupona, 1992). That the migrants indeed combined weaving with cleric job is plausible. The site where the Muslim Ummah (faithfuls) first gathered and prayed in 1888 was Oke-Otunba where the present central mosque now stands. The same area extending to Igbonmoba and some parts of Surulere is known to have accommodated the largest number of narrow hand-loom weavers in the history of Ondo between the 1920s and late 1960s. It is in this same area where Ene (1964) met Alfa Yesufu, the sanyan weaver in 1960. Although their sheds have since given way to residential buildings, a few of the migrant weavers still live in the area. Most of the few weavers left now (occasionally) combine weaving with other jobs.

There is no record to show the involvement of Ondo indigenes in the narrow strip cloth (aso-òkè) weaving since its beginning in the region. The oral data available showed that, the few who have been involved in the business have been doing so as entrepreneurs, who employed the services of weavers to meet the demands of their patrons. Before the arrival of the Iseyin and llorin weavers as well as the introduction of narrow loom weaving in Ondo, local tradition had it that the Ondo clothiers of old were collecting àláárì, etù and sányán from the known major markets of the time, particularly Òjé market in ìbàdàn. Yeye Chief Adepoju the Sàsèrè Lóbùn of Ile-Oluji confirmed this by saying that, "Our mothers used to go to İbàdàn, Iseyin and Ede and sometimes as far as llorin on foot to buy aso-òkè. They often went with mat and ailee (local broom) to sell and in-turn buy aso-òkè from the markets to be re-sold at the local markets in Ondo, Ile-Oluji, İdànrè and other nearby markets" (personal communication, 1999). Mama Ayodele Akano, the lyálójà aláso-òfi5 - the head of hand woven textile merchants at also confirmed the long presence of Ondo aso-òkè merchants at Oje. She said that her father, who was also her predecessor, told her that the Ondo people have been coming to Oje to collect asoofi since the inception of the market in the middle of the nineteenth century Oje market (personal communication, 2001).

The only known weaving related craft in Ondo is dyeing. The people of Oke-Osun quarters were said to be complementing the weaving and the maintenance of the aso-òkè industry by dyeing the spun yarn and helping aso-òkè users to retouch the fading ones (Awogbamiye, personal communication, 1999). Yèyé Lísà-Lòbùn Olamoju of this quarter (Oke-Osun) was a paramount dyer who was also trading in àdire (Fawehinmi 1991). There are some other individuals who engaged in the cleaning and 'beating' (Iilù) of aso-òkè. Besides these, the Ondo are generally collectors of aso-òkè.. Mama Akingbola Mama Osowo and Yèyé Sàréré-Lóbùn Adepoju of Ile-Oluji in separate interviews confirmed the fact that "Ondo people don't weave" According to them, "our mothers only collect and sell" (personal communication, 1999). It is not impossible to have had some young Ondo indigenes that may have developed interest in narrow strip weaving between the 1920s and 1960s, but their number must have been very insignificant and ignorable. The Ondo's exposure to fast business may even have made such people abandon narrow strip weaving. 
The major contribution of Ondo indigenes to the manufacture of aso-òkè was in the supply of materials particularly the 'silk' before the emergence of imported yarn. The aghàsá tree, which feeds the anaphe caterpillar that produce cocoon, which is normally used in making the silk yarn for sanyan, was abundant in the Ondo forest (Mama Afusatu, Personal Communication, October , 2001) ${ }^{6}$. The trees spread from Ondo to Oke-Igbo and to the interior farm settlements and villages. The caterpillars, which make good food, are seen on these trees mostly around the third quarter of the year. It is very possible that a few indigenes, like Mama Mofeade's mother earlier mentioned, who had the idea of carding and spinning, may have been involved in preparing silk thread cocoon. Mama Afusatu of Oke-Igbo from whom this researcher bought a cocoon pod and some roasted caterpillars confirmed this possibility. She said that Oke-Igbo women used to spin èwùkù for sale to weavers who usually come from Ondo and some other Oyo towns. The manufacture of aso-òkè flourished in Ondo between the 1920s and 1960s. It provided the women clothiers the opportunity of getting their wares not only from far away Ibadan, Iseyin and Ilorin but also within the kingdom.

\section{Decline in the Weaving of Aso-Òkè in Ondo and the Departure of the Migrant Weavers}

While it can well be said that the weaving of aso-òkè flourished in Ondo town and its environs in the very early part of the twentieth century up to the 1960s, the weaving of the old aso-òkè types in the town, has actually started to decline since the 1920s. This is as a result of a number of factors, topmost of which was the emergence of imported fabrics that seem to be more fanciful and cheap. These fabrics included Damask, Croydon, Brocade and some series of 'velvet' àrán- and even printed fabrics - ànkárá. The preference for these new fabrics led to the initial decline in the patronage of aso-òkè.

Furthermore, the change in fashion trends that began around the 1930s further contributed to the decline in the use of aso-òkè, by many, even as ceremonial cloths. The presence of missionaries, colonial officials and returnee slaves, who came in with different western dress-habits towards the close of the 19th century caught the attention of and influenced the Yorùbá especially those who were close to the coast (Duncan 1998). Those who had cause to trade in Lagos and some urban cities, like the Ondo people, were also not left out. It became fashionable for men to dress in suits and sometime shirts and shorts, while women appeared in flowing skirts and gowns. There were also particular dress styles for certain occasions and appointments, such as office and wedding dresses. All these affected the use of aso-òkè.

Another major factor was the introduction of machine spun cotton and imported dye stuffs. Picton and Mark (1989) suspected that the influx of these foreign materials was a deliberate attempt by the colonial powers to subvert the local cultivation of cotton. By the 1930s, weavers had found it more convenient to use the already dyed machine spun cotton, thus abandoning the hand spun cotton, which they found too cumbersome and time consuming to prepare. This led to the gradual collapse of the cotton spinning tradition, and gave rise to the shortage of hand spun cotton and silk. It also created a further decline in the manufacture of the old aso-òkè types. Alhaji Kazeem Ajadi noted that, initially, weavers were combining hand-spun cotton with machine spun cotton, but later, particularly around the 1940s and towards the close of the 1950s, most weavers were already using the machine spun cotton and rayon on a very large scale. According to him, a few elderly weavers who could not easily adjust to the use of the chemical dyes were using the local dyes on the machine -spun cotton to derive something close to the old cloth types (personal communication, 2001).

While young aso-òkè weavers in Ibadan, Osogbo, Ogbomoso and even Iseyin and llorin were adjusting to the new materials and were making some innovations and improvements to sustain patronage, the young migrant weavers in Ondo were returning home for lack of patronage. For the Ondo, nothing seems comparable to the old aso-òkè type made of hand-spun cotton. The Ondo people would rather buy the used old aso-òkè types that are already sewn into dresses, which they believe last longer and are fast in color than commissioned cloths made of new threads. Yemi Depitan an Ondo indigene and a prominent aso-òkè merchant introduced a remarkable innovation into the trade in the 1940s by commissioning the weavers to recopy patterns generally known to be acceptable to the Ondo with some new color patterns using pure machine spun cotton and rayon (Akingbola, personal Communication, 1999). The cloths made of this process are called Yemi Depitan types (Mama Oshowo, Personal Communication, 1999). According to Mama Oshowo, an aide of Yemi Depitan, Depitan used to go as far as Ilorin, Iseyin and Oyo to commission cloth weavers particularly the elderly ones. She added that Depitan's efforts, were initially disregarded as people openly mocked those who wear her types derogatively saying le òo l'aso Dépitàn, literarily meaning 'see her, Depitan's customer". The mockery however has stopped since the 1970s with the collapse of the manufacture of the old aso-òkè types. The Ondo have come to accept and value Depitan's types which are also no longer available in strips, but as sewn and used dresses.

By the middle of the 1960s, only the weavers of sanyan cloth sustained the weaving industry in Ondo basically because they still got supplies of anaphe silk yarn from local spinners. According to Mama Afusatu, the supply of ewùkù to the Ondo weavers usually came from the surrounding towns and villages such as Oke-Igbo and Idanre (personal communication, 2001). The few other weavers who were working with new threads were mainly using Ondo as their 
base, but their patronage was mostly from outside Ondo. Ene (1964), who visited Ondo around this period, met these sanyan weavers, and this informed his thinking that Ondo was an major weaving centre.

Also of significance to the decline of the old aso-òkè manufacture in Ondo was the felling of the trees, particularly the aghasa tree. This tree naturally hosts the caterpillar that also produces the cocoons used for spun silk. According to Awogbamiye, most of the trees were cleared to give way to the construction of buildings and roads around the early 1970s (personal communication, 1999). The resultant scarcity of anaphe cocoon and the Ondo preference for the old aso-òkè types, which left the few remaining weavers with no patronage, must have led to the consequent collapse of the narrow strip weaving industry in Ondo. Even most of the young girls who were apprenticed in the 1980s have abandoned the narrow loom weaving for the same reason. The few young weavers left in Ondo, as at the year 2000 were more or less part-time weavers. Alagba Alarape an Ondo based llorin weaver ${ }^{7}$, claims that these few weavers relied more on the patronage of non-Ondo indigenes in the town and its suburbs who order for the new aso-oke types as aso-ebi for weddings and some other ceremonies (personal communication, 2001).

\section{Conclusion}

The consistency in the use of the old aso-òkè type by the Ondo, which can be said to have conferred on the cloth the status of "Ondo identity", may have made many people to erroneously arrogate to Ondo people a long history of aso-òkè weaving tradition. That the Ondo indigenes are not weavers but good merchants and patrons of the old aso-òkè types has been established in this paper. The paper has also established the fact that Ondo town which enjoyed being a flourishing narrow loom weaving centre for about four to five decades from the early part of the 20th Century was indeed sustained by the migrant weavers from Iseyin and llorin. This study has afforded an opportunity of documenting the history of aso-òkè manufacture in Ondo Town.

\section{References}

Adeyemi, M. C. 1993. Ondo Kindom: Its History and Culture. Ibadan: Bounty Press

Aronson, L. 1992. "ljebu Yoruba Aso-Olona: A Contextual and Historical Overview." African Arts Vol. XXV No. 3: 52-69.

Duncan, C. 1997. The Art of African Textile. London: Promotional Reprint.

Ene, C. 1964. "Indigenous Silk Weaving in Nigeria." Nigeria Magazine 81: 127-136.

Fajana, A. and Biggs B. J. 1964. Nigeria in History. Ibadan: Longman.

Fawehinmi, F. 1991. Makers of Ode-Ondo Part 1, 2 \& 3. Ondo: Fawehinmi Library

Johnson, S. 1921. History of the Yoruba. Lagos: C.S.S. Bookshop

Lamb, V. and Holmes D. 1980. Nigerian Weaving. Hertingfordbury: Rexford Books

Leigh, J. A. (1917) The History of Ondo. Ondo:

Ogunsakin, P. 1976. Ondo: The People, Their Culture and Traditions. Lagos: Inway

Ojo, J. O. (Bada of Shaki). 1962. Iwe-Itan Ondo. Ondo: Fouth Pub

Olupona, J. K. 1992. Kingship, Religion and Rituals in a Nigeria Community: A Phenomenological Study of Ondo Yoruba Festival. Ibadan: Layday.

Picton, J. and Mack, J. 1989. African Textile. London: British Museum.

\section{Notes}

Mama Adeduro Agnes' (aged 96 of Fidipote Street, Ondo) aunt who came from llesa was an upright loom cloth weaver

Pa Lucas Akinola of Oke-lgbo, aged 84 was trained at Textile Industry Ado-Ekiti after the discharge from the Army by the end of the World war II. He used to weave on a modified Industrial Loom.

koololo is a mockery 'name' often used by the Ondo people for alien in their midst especially those from Oyo area (Ibadan, Iwo, Osogbo, Iseyin etc)

Mama Akingbola, aged 72, an Ondo clothier, is the daughter of Yemi Depitan a famous aso-oke clothier between 1940 and 1970

Mama Ayodele Akano, aged 82 was the Iyaloja of Oje market as at the time of the field work for this study.

Mama Afusatu of Oke-lgbo, aged 60, is a clothier who also collects anaphe cocoon for sales.

Alarape, aged 48. An llorin migrant weaver still leaves around the weaving centre in Surulere/lgbonmoba area of Ondo as at the time of the field work for this study. 